\title{
Earliest Evidence for Ground-Edge Axes: $35,400 \pm 410$ cal BP from Jawoyn Country, Arnhem Land
}

\author{
Jean-Michel Geneste ${ }^{1}$, Bruno David ${ }^{2}$, Hugues Plisson ${ }^{3}$, Chris Clarkson ${ }^{4}$, \\ Jean-Jacques Delannoy ${ }^{5}$, Fiona Petchey ${ }^{6}$ and Ray Whear ${ }^{7}$
}

\begin{abstract}
Evidence for the world's earliest stone tools dates to 3.4 million years ago and pre-dates the earliest known Homo species in eastern Africa. However ground-edged tools did not appear until the dispersal of cognitively fully modern Homo sapiens sapiens out of Africa. We report on the discovery of the earliest securely dated ground-edge implement in the world at Nawarla Gabarnmang (northern Australia). The fragment of ground-edge axe is sandwiched between four statistically indistinguishable AMS radiocarbon dates of $35,400 \pm 410 \mathrm{cal}$ $\mathrm{BP}$, indicating technological innovations by fully modern Homo sapiens sapiens at the eastern end of the Out-of-Africa 2 Southern Arc dispersal route.
\end{abstract}

\section{Introduction}

While evidence for stone tool-use among our archaic hominin ancestors dates to 3.4 million years ago (McPherron et al. 2010; Semaw et al. 1997), the first use of grinding to shape stone tool edges such as axes is clearly associated with Homo sapiens sapiens. While grinding as a technology is much older than the colonisation of Australia (such as for the preparation of ochre; e.g. Henshillwood and d'Errico 2005; Soressi and d'Errico 2007), ground-edged tools do not see their earliest appearance in Africa like so many other important technologies (Henshilwood et al. 2002), but in Australia - at the eastern end of the Out-of-Africa 2 dispersal of modern humans sometime after 80,000 years ago. The late appearance of edge-grinding to make cutting or chopping tools - long after complex projectile and composite tools first appeared elsewhere - supports a mosaic-like origin of cultural complexity within our species, with complex new technologies appearing gradually, sometimes with multiple independent origins. New evidence for the earliest securely dated ground-edge implement in the world indicates that Australia was in this way an important locale of technological innovation 35,000 years ago.

\footnotetext{
Centre National de Préhistoire UMR 5199 CNRS PACEA, Université de Bordeaux 1, Talence, France jean-michel.geneste@culture.gouv.fr 2 Programme for Australian Indigenous Archaeology, School of Geography and Environmental Science, Monash University, Clayton, VIC 3800, Australia bruno.david@monash.edu

${ }^{3}$ CNRS, UMR 5199 PACEA, Université de Bordeaux 1, Talence, France hugues.plisson@pacea.u-bordeaux1.fr

School of Social Science, The University of Queensland, QLD 4072, Australia c.clarkson@uq.edu.au

${ }^{5}$ EDYTEM - UMR 5204 du CNRS - ‘Environnements, Dynamiques et Territoires de la Montagne', Centre Interdisciplinaire Scientifique de la Montagne, Université de Savoie, F 73376 Le Bourget du Lac Cedex, France Jean-Jacques.Delannoy@univ-savoie.fr

${ }^{6}$ Radiocarbon Dating Laboratory, University of Waikato, Hamilton 3240, New Zealand fpetchey@waikato.ac.nz

Jawoyn Association Aboriginal Corporation, PO Box 371, Katherine, NT 0851, Australia ray.whear@jawoyn.org
}

\section{Nawarla Gabarnmang}

Archaeological excavations undertaken in May 2010 at Nawarla Gabarnmang in northern Australia, 43km and $105 \mathrm{~km}$ respectively from Australia's two earliest known Aboriginal sites Nauwalabila 1 (Roberts et al. 1993) and Malakunanja II (Roberts et al. 1998), reveal two AMS radiocarbon determinations of 30,615 $\pm 309 \mathrm{BP}$ (Wk-28616) and 31,316 \pm 618 BP (Wk-28130) above a fragment of ground-edge axe and two determinations of $30,761 \pm 314 \mathrm{BP}$ (Wk-28621) and 31,063 $\pm 595 \mathrm{BP}$ (Wk-28131) immediately below it (Table 1). The four charcoal samples were taken from the lower excavation units (XUs), namely XUs 28-31 in Stratigraphic Unit 5 (SU5), surrounding the fragment of ground-edge axe located in XU30. The AMS radiocarbon samples were prepared at the Waikato Radiocarbon Dating Laboratory in New Zealand using a standard acid-base-acid treatment (Olsson 1986). Graphite targets were prepared by the reduction of cryogenically purified $\mathrm{CO}_{2}$ to graphite, using hydrogen over pre-cleaned iron powder at $550^{\circ} \mathrm{C}$. The radiocarbon results were calibrated using IntCal09 (Reimer $e t$ al. 2009) in OxCal v4.1.7 (Bronk Ramsey 2009) and produced a combined statistically indistinguishable age of 36,230-35,880 and $35,580-34,850 \mathrm{cal} \mathrm{BP}$, equivalent to a mean age of $35,400 \pm 410 \mathrm{cal}$ BP for the four SU5 samples (95.4\% prob.; $\left.\chi_{3: 0.05}^{2}=1.232<7.815\right)$. This represents the earliest known ground-edge axe in the world, with the previous securely dated oldest examples dated to 22,00030,000 BP from Japan and northern Australia (O'Connor 1999; O'Connor and Veth 2006; Oda and Keally 1992; Schrire 1982; Zhao et al. 2004; see also Morwood and Trezise 1989 for a report of a purportedly similarly-aged, lost axe excavated by amateur researchers in Cape York Peninsula in the 1960s).

Nawarla Gabarnmang is a large rockshelter in Jawoyn Aboriginal country in southwestern Arnhem Land. Located on top of the escarpment in the Kombolgie Formation, it consists of stable and hard orthoquartzite and softer and less stable quartz sandstone bedrock subject to in situ weathering through hydration and solution processes along bedding planes and fissure lines. The double-ended rockshelter has a subhorizontal ceiling ranging from $1.75 \mathrm{~m}$ to $2.45 \mathrm{~m}$ above floor level. The area under the well-protected overhang is $19 \mathrm{~m}$ long by $19 \mathrm{~m}$ wide and provides shelter for rich cultural sediments entirely protected from rainfall. Charcoal is abundant throughout the excavated deposit.

Square A at Nawarla Gabarnmang consists of a $50 \mathrm{~cm} \mathrm{x}$ $60 \mathrm{~cm}$ sounding excavated in mean $1.8 \mathrm{~cm}$-thick XUs following the observed stratigraphy. Cultural items $\geq 2.0 \mathrm{~cm}$ long and individual fragments of charcoal observed in situ were plotted in three dimensions. Bedrock was reached at $66.2 \mathrm{~cm}$ below surface. All other excavated sediments were sieved in $2.1 \mathrm{~mm}$ mesh sieves and residual materials were bagged for laboratory analysis. 


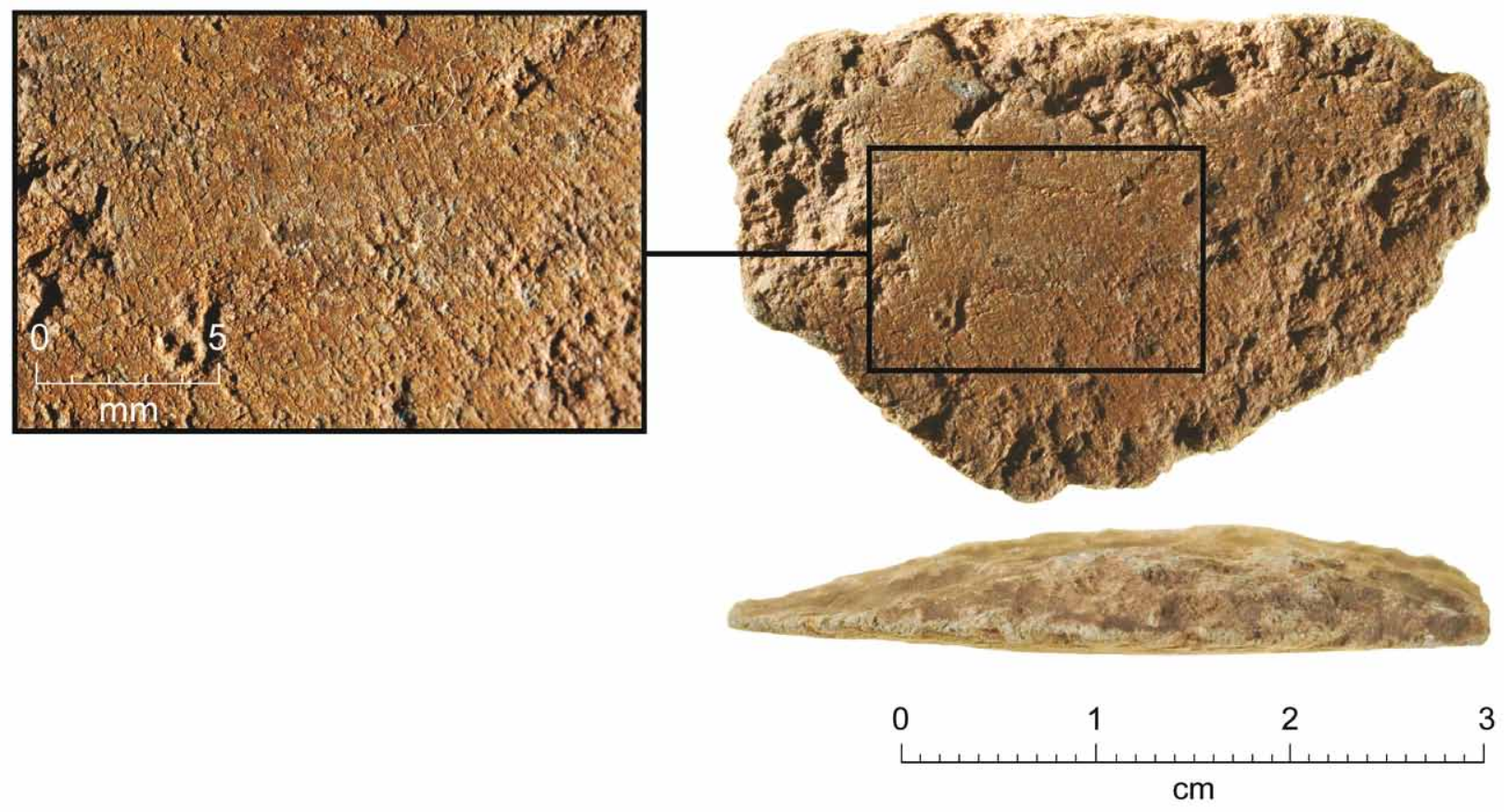

Figure 1 The Pleistocene ground-edge fragment from XU30 of Square A, Nawarla Gabarnmang. Grinding striations are clearly visible on the dorsal surface of the artefact (Photograph: Steve Morton).

The deepest and oldest layer above bedrock is SU5. The ground-edge axe fragment comes from XU30 in SU5 of Square A, at a depth between $47.7 \mathrm{~cm}$ and $50.4 \mathrm{~cm}$ below the present surface (Figure 1). Sediments in each of the five SUs consist of compact and well-consolidated loamy sands produced by chemical alteration of the surrounding sandstone bedrock and accumulated aeolian sediments. The terminal Pleistocene sediments of SU4, incorporating the Last Glacial Maximum into the Pleistocene-Holocene boundary, consist of a layer of exfoliated sandstone roof fall rocks infilled with compact loamy sands sealing the underlying SU5 (which contains the fragment of ground-edge axe reported here) from overlying sediments. It was explicitly noted during excavation that no evidence for sediment turbation was apparent, that no rootlets were evident, and that generally pieces of rock (including stone artefacts) were lying flat within SU5. Further support for the reliability of the chrono-stratigraphic sequence, and with this the age of the fragment of ground-edge axe, is found in the good chronostratigraphic order of the 18 radiocarbon determinations from Square A, each undertaken on a single piece of charcoal collected in situ and plotted in three-dimensions (full details of the
Nawarla Gabarnmang excavations are in preparation). Together these characteristics of the sediments enveloping the ground artefact, and the artefact's highly weathered state consistent with the other stone artefacts from SU5 (noticeably different to the Holocene artefacts) mitigate against the possibility of its postdepositional vertical redeposition from higher levels.

Throughout the excavated sequence stone artefacts made of quartzite and chert number in the thousands, but preliminary analysis of the excavated artefacts indicate that the fragment of ground-edge axe reported here is the only volcanic artefact found. The stone raw material from which the ground-edge fragment is made is crystalline, of a basaltic type with reasonably fine crystals. The surface is chemically altered. The closest possible source of basalt is $37 \mathrm{~km}$ to the southeast.

\section{The Ground-Edge Axe Fragment}

The ground artefact is a thin flake detached by percussion from a rectilinear edge. It measures $2.55 \mathrm{~cm} \times 3.93 \mathrm{~cm}$ and is $0.61 \mathrm{~cm}$ in thickness. The ventral surface clearly reveals the crystalline structure of the rock. The point of impact from which the flake was detached can be clearly distinguished. The flake exhibits

Table 1 Radiocarbon data from Nawarla Gabarnmang, Square A, Stratigraphic Unit 5.

\begin{tabular}{|c|c|c|c|c|c|}
\hline $\mathbf{X U}$ & $\begin{array}{l}\text { Depth } \\
\text { (cm) }\end{array}$ & Lab No. & $\begin{array}{l}\delta 13 C \% \\
( \pm 0.2)\end{array}$ & $\begin{array}{l}\text { Conventional } \\
\text { Radiocarbon Age } \\
\text { (BP) }\end{array}$ & Calfbrated Age BP \\
\hline XU28 & 46.6 & Wk-28616 & 23.7 & $30,615 \pm 309$ & $\begin{array}{l}36,120-36,020,35,340-34,730 \text { cal BP }(68.3 \%) \\
36,260-35,820,35,640-34,620 \text { cal BP }(95.4 \%)\end{array}$ \\
\hline XU29 & 46.5 & Wk-28130 & 25.4 & $31,316 \pm 618$ & $\begin{array}{l}36,420-35,200 \text { cal BP }(68.3 \%) \\
37,110-34,690 \text { cal BP }(95.4 \%)\end{array}$ \\
\hline XU31 & 51.4 & Wk-28621 & 24.2 & $30,761 \pm 314$ & $\begin{array}{l}36,170-35,960,35,460-34,850 \text { cal BP }(68.3 \%) \\
36,290-35,760,35,710-34,720 \text { cal BP }(95.4 \%)\end{array}$ \\
\hline XU31 & 52.7 & Wk-28131 & 24.7 & $31,063 \pm 595$ & $\begin{array}{l}36,280-35,760,35,740-35,070 \text { cal BP }(68.3 \%) \\
36,710-34,650 \text { cal BP }(95.4 \%)\end{array}$ \\
\hline
\end{tabular}


no evidence of further modification following detachment. Its morphology shows that it was removed from the surface of the original tool.

The dorsal surface of the flake is smooth, slightly convex across its widest axis and slightly less convex in length. Under acute-angled light it exhibits extensive grinding striations along its entire length. The flake was ground smooth with a relatively fine-grained raw material, potentially sandstone of the local Kombolgie Formation.

The abraded surface contains a homogeneous central raised facet, ground smooth along its upper reaches; along its slope the relief becomes coarser with an increasing density of shallow surface depressions, vestiges of prior hammer dressing (pecking) or of the original surface of the rock. On the raised facet sets of superimposed and criss-crossing bands of striations notable for their short length $(0.5 \mathrm{~cm}$ on average $)$ can be distinguished under binocular microscope (10X magnification).

The ends of the abraded striations along the edge of the flake are flush with the detachment edge, which eliminates the possibility that the artefact was ground after becoming detached from the axe. There is no evidence of subsequent modification in the form of retouch or subsequent grinding.

Although the flake does not intersect the cutting chord of the original tool, its attributes exclude the possibility that it could be a portion of grinding stone or percussion tool. The ground flake, wider than it is long, with a large straight butt and dorsal surface evenly ground to a slight convexity prior to its detachment, indicates with certainty that it is a lateral fragment of the cutting surface of a ground-edge axe. The percussion angle is close to $90^{\circ}$ with the dorsal surface, and the precision of application of percussion force combined with the thinness of the removed flake indicates an intentional action. The removal of the flake was aimed at thinning a side of the axe, near its lateral margin and fairly close to the effective cutting edge so as to remove a small protuberance indicated by a concentration of short, multidirectional striations.

\section{Discussion}

The Nawarla Gabarnmang fragment of ground-edge axe represents the oldest confirmed ground-edged stone tool in the world. Stone artefacts and fragments of roof fall within the compact sediments of SU5 which contain the ground-edge fragment generally lie flat in the ground; are only associated with statistically indistinguishable radiocarbon determinations; were excavated in thin, mean $1.8 \mathrm{~cm}$ XUs following the observed stratigraphy thereby avoiding as much as possible mixing sediments of different ages; are sealed by a terminal Pleistocene layer of roof fall which itself contains well consolidated loamy sands; are devoid of evidence of rootlet, insect or other animal disturbance; are well protected from rainfall and driplines; and are part of a long sequence of 18 AMS determinations on single pieces of charcoal which lie in good chrono-stratigraphic order. The sum of these factors indicates the reliability of chronostratigraphic results. Considered in the context of 22,00030,000 BP ground-edge axes from Japan and other Australian sites (Morwood and Trezise 1989; O'Connor 1999; O'Connor and Veth 2006; Oda and Keally 1992; Schrire 1982; Zhao et al. 2004), it suggests that ground-edge axes were first invented along the Pacific rim by fully modern Homo sapiens sapiens towards the end of, or following, the Out-of-Africa 2 dispersal (Balme et al. 2009; Veth et al. in press). Reports of much older flaked and waisted (but not ground) axes from New Guinea (Anderson and Summerhayes 2008; Groube et al. 1986; Summerhayes et al. 2010) suggest that axe technology evolved into that of grinding for sharper, more symmetrical and maintainable edges (see Dickson 1981 for a classic text on Australian ground-edge axes). Hence Sahul was a centre for multiple innovations in axe technology. Axes fulfilled a unique position within the Aboriginal toolkit as long use-life chopping tools that were labour intensive to manufacture, highly valued and later exchanged over long distances (Brumm 2010; Hiscock 2005). The ground fragment from Nawarla Gabarnmang provides the most recent and secure terminus ante quem for the technological, social and symbolic transformations that must have accompanied the introduction of this distinctive new technology.

\section{Acknowledgements}

We thank the Jawoyn Association Aboriginal Corporation Committee, and Margaret Katherine, Sybil Ranch, Preston Lee, Wes Miller and Ray Whear, for inviting and caring for us during research in their country. Thanks to Ben Gunn in the field, Lance Syme for assisting in the excavation, Luke Weatherley for sorting, Steve Morton for photography, Toby Wood for assembling Figure 1 and Chris Morgan for the helicopter views and co-rediscovering the site with Ray Whear. Thanks to Richard Fullagar, Ian McNiven, Sean Ulm, Peter Veth and an anonymous referee for useful comments.

\section{References}

Anderson, A. and G. Summerhayes 2008 Edge-ground and waisted axes in the western Pacific islands: Implications for an example from the Yaeyama Islands, southernmost Japan. Asian Perspectives 47:45-58.

Balme, J., I. Davidson, J. McDonald, N. Stern and P. Veth 2009 Symbolic behaviour and the peopling of the southern arc route to Australia. Quaternary International 202:59-68.

Bronk Ramsey, C. 2009 Bayesian analysis of radiocarbon dates. Radiocarbon 51(1):337-360.

Brumm, A. 2010 'The falling sky': Symbolic and cosmological associations of the Mt William greenstone axe quarry, central Victoria, Australia. Cambridge Archaeological Journal 20(2):179-196.

Dickson, F. 1981 Australian Stone Hatchets: A Study in Design and Dynamics. Sydney: Academic Press.

Groube, L., J. Chappell, J. Muke and D. Price 1986 A 40,000 year old occupation site at Huon Peninsula, Papua New Guinea. Nature 324:453-455.

Henshilwood, C.S. and F. d'Errico 2005 Being modern in the Middle Stone Age: Individuals and innovation. In C. Gamble and M. Porr (eds), The Individual Hominid in Context: Archaeological Investigations of Lower and Middle Palaeolithic Landscapes, Locales and Artefacts, pp.244-264. Abingdon: Routledge.

Henshilwood, C.S., F. d'Errico, R. Yates, Z. Jacobs, C. Tribolo, G.A.T. Duller, N. Mercier, J.C. Sealy, H. Valladas, I. Watts and A.G. Wintle 2002 The emergence of modern human behavior: Middle Stone Age engravings from South Africa. Science 295:1278-1280.

Hiscock, P. 2005 Blunt and to the point: Changing technological strategies in Holocene Australia. In I. Lilley (ed.), Archaeology of Oceania: Australia and the Pacific Islands, pp.69-95. Oxford: Blackwell.

McPherron, S.P., Z. Alemseged, C.W. Marean, J.G. Wynn, D. Reed, D. Geraads, R. Bobe and H.A. Béarat 2010 Evidence for stone-tool-assisted consumption of animal tissues before 3.39 million years ago at Dikika, Ethiopia. Nature 466:857-860. 
Morwood, M.J. and P. Trezise 1989 Edge-ground axes in Pleistocene Greater Australia: New evidence from S.E. Cape York Peninsula. Queensland Archaeological Research 6:77-87.

O'Connor, S. 1999 30,000 Years of Aboriginal Occupation: Kimberley, North West Australia. Terra Australis 14. Canberra: Research School of Pacific and Asian Studies, Australian National University.

O'Connor, S. and P. Veth 2006 Revisiting the past: Changing interpretations of Pleistocene settlement subsistence and demography in northern Australia. In I. Lilley (ed.), Archaeology of Oceania: Australia and the Pacific Islands, pp. 3147. Oxford: Blackwell.

Oda, S. and C.T. Keally 1992 The origin and early development of axe-like and edge-ground stone tools in the Japanese Palaeolithic. IPPA Bulletin 12:23-31.

Olsson, I. 1986 Radiometric methods. In B. Berglund (eds), Handbook of Holocene Palaeoecology and Palaeohydrology, pp.273-312. Chichester: John Wiley and Sons.

Reimer, P., M. Baillie, E. Bard, A. Bayliss, J. Beck, P. Blackwell, C. Bronk-Ramsey, C. Buck, G. Burr, R. Edwards, M. Friedrich, P. Grootes, T. Guilderson, I. Hajdas, T. Heaton, A. Hogg, K. Hughen, K. Kaiser, B. Kromer, F. McCormac, S. Manning, R. Reimer, D. Richards, J. Southon, S. Talamo, C. Turney, J. van der Plicht and C. Weyhenmeyer 2009 Intcal09 and Marine09 radiocarbon age calibration curves, 0-50,000 years cal BP. Radiocarbon 51(4):1111-1150.

Roberts, R.G., R. Jones and M.A. Smith 1993 Optical dating at Deaf Adder Gorge, Northern Territory, indicates human occupation between 53,000 and 60,000 years ago. Australian Archaeology 37:58-59.
Roberts, R., H. Yoshida, R. Galbraith, G. Laslett, R. Jones and M. Smith 1998 Singlealiquot and single-grain optical dating confirm thermoluminescence age estimates at Malakunanja II rock shelter in northern Australia. Ancient TL 16:19-24.

Schrire, C. 1982 The Alligator Rivers: Prehistory and Ecology in Western Arnhem Land. Terra Australis 7. Canberra: Australian National University Press.

Semaw, S., P. Renne, J.W.K. Harris, C.S. Feibel, R.L. Bernor, N. Fesseha and K. Mowbray 1997 2.5-million-year-old stone tools from Gona, Ethiopia. Nature 385:333-336

Soressi, M. and F. d'Errico 2007 Pigments, gravures, parures: Les comportements symboliques controversés des Néandertaliens. In B. Vandermeersch and B. Maureille (eds), Les Néandertaliens: Biologie et Cultures, pp.297-309. Éditions du CTHS, Documents Préhistoriques 23. Paris.

Summerhayes, G.R., M. Leavesley, A. Fairbairn, H. Mandui, J. Field, A. Ford and R. Fullagar 2010 Human adaptation and plant use in highland New Guinea 49,000 to 44,000 years ago. Science 330:78-81.

Veth, P., N. Stern, J. McDonald, J. Balme and I. Davidson in press The role of information exchange in the colonization of Sahul. In B. Whallon, B. Lovis and B. Hitchcock (eds), The Role of Information in Hunter-Gatherer Band Adaptations. Los Angeles: UCLA.

Zhao, C., X. Wu, T. Wang and X. Yuan 2004 Early polished stone tools in South China evidence of the transition from Palaeolithic to Neolithic. Documenta Praehistorica 331:131-137. 